\title{
Revolting Animation: The Hierarchy of Masculinities in the Representation of Race and Male Same-Sex Desire in Adult Cartoons
}

\author{
IRENE FUBARA-MANUEL, University of Sussex
}

\begin{abstract}
This article examines the representations of race and male same-sex desire portrayed by black gay male characters on the adult animated television show, The Boondocks (2005). Centralizing its analysis of The Boondocks as a canonical text of black gay representation within animation, this paper highlights the signs of the male matriarch, booty warrior, and homothug and their iterations in three other animated TV shows-The Cleveland Show (2009), American Dad! (2005), and Chozen (2014). This article posits that these signs connote the ideology of hegemonic masculinity and its racial ordering. Drawing on Halberstam's (2011) 'revolting animation', Ngai’s (2005) 'animatedness', and Wells' (1998) 'hierarchies of masculinities', this article addresses these contradicting signs of black gay masculinities within the aforementioned animated television shows, situating them within respective sexual and racial politics in the United States.
\end{abstract}

\section{KEYWORDS}

Hegemonic masculinity, animation, representation, race, sexuality

In the chapter addressing the genealogy of representation in animation, Animation Studies scholar Paul Wells (1998) coins the term 'the hierarchy of masculinity' (194) to describe the supremacy of white masculinity represented in the 1943 animated short film Jungle Drums, where Superman battles Nazis and dark-skinned natives to rescue Lois Lane. Attesting to this persistent hierarchy, contemporary scholars outside of Animation Studies, such as Richard King, Carmen Lugo-Lugo, and Mary Bloodsworth-Lugo (2010) and Sianne Ngai (2005), address the imperialist, racist and heterosexist discourses injected into animation. Judith Halberstam (2011), however, notes these racialised discourses within animation, but also praises the genre for its radical potential to stage revolts. As such, this article, addresses the marginalisation of black gay masculinities within animation, borrowing from Ngai's (2005) theory of 'animatedness' and Halberstam's (2011) theory of 'animated revolt' to address the system of hegemonic masculinity in animation.

To be “"animated” in American culture is to be racialized in some way', Ngai (2005, 95) notes, as the process of animation highlights the agency of the animator over the object 'being moved' (91). This conceptualisation of animatedness doubly connotes a stereotypical representation of racialised characters as 'excessive'. Canonising the 1999 television show The PJ's as 'the first primetime program in American television history to feature a completely non-white, non-middle class, and non-live action cast' (102), Ngai highlights excess in The PJ's through the socio-economic disenfranchisement of its characters and its 'ugly' character design. By incorporating this excess, similar to a number of films and 
television programs this article explores, The PJ's subverts the racial stereotypes it deploys by infusing critical discourse into them. These characterisations of excess in this 1990s TV show also have gendered and sexualised implications. Ralph Bakshi, for example, in his 1975 cult classic, Coonskin, caricatures a group of gay brothers as incestuous, villainous, drag queens. A controversial piece, which incited protests from the Congress of Racial Equality (Cohen 2004), this film uses live action and animation to satirise Disney's representation of black people as happy slaves in Song of the South (1946) or chuckin' and jivin' Negros in Dumbo (1941). By appropriating the characters Brother Rabbit, Brother Bear, and Preacher Fox from Song of the South as streetwise radical pro-Black hustlers, Bakshi re-imagines these excessive racial stereotypes in the form of revolt.

As Halberstam (2011) illustrates, several animated films glorify the queer art of failure and 'revolt'. 'Pixarvolt', Halberstam names the type of animation, has created 'a new space for the imagining of alternatives' $(2011,48)$. The queer theorist elucidates, 'gender in these films is shifty and ambiguous [...]; sexualities are amorphous and polymorphous [...]; bodily ability is often at issue' (47-48). The films revolt against capitalism, (cis)genderism, heteronormativity, and the individualistic ideal of neoliberalism. Darting across several forms of animation, Halberstam highlights the feminist utopia within stop animation Chicken Run (2000); the homoeroticism between SpongeBob and Patrick in the 2D animated Nickelodeon series SpongeBob SquarePants (1999); and queer constructive birthing of a baby robot in Robots (2005). Un-revolting animation, Halberstam extricates, places the self-actualised individual above the diverse collective, prioritising the narrative of family and romance over radical possibilities.

In this sense, this article offers a semiotic textual analysis of animated revolt against hegemonic masculinity located within its central text-The Boondocks (2005). It also reads three other animated adult television programs—Chozen (2014), American Dad! (2005), and The Cleveland Show (TCS) (2009)—for their iterations of the signs and radical possibilities of black gay gender performance in adult animation. First laying out its choice of texts and clarifying the centralisation of The Boondocks, it then turns its direction to an analysis of these TV shows. Expanding on the theoretical framework of hegemonic masculinity (Connell 2005), this article maps the position of black gay men within these texts. It addresses some issues in the political economy that frame this positionality and the representations of black and gay masculinities in the media at large. On the one hand, mapping out moments of animated revolt against heteronormativity and hegemonic masculinity, while on the other, analysing moments of complicity to this system, this article illustrates the complex, often contradicting, representations of black gay masculinity within animation and the implications of these representations within the larger hegemonic system.

\section{Black Gay Men and Hegemonic Masculinity}

According to Raewyn Connell (2005), definitions of masculinity either assign core cultural value, a statistical commonality or an aspirational norm as the definition of masculinity. Connell explains masculinity as a 'place in gender relations, the practices through which men 
and women engage that place in gender, and the effects of these practices in the bodily experience, personality and culture' $(2005,71)$. Although Connell's definition does not take into account the masculinity within women, Halberstam (1998) has skilfully expounded on female masculinity. Connell, however, emphasises the relation of masculinities within the gender order as: hegemonic, subordinate, complicit and marginal. Connell defines hegemonic masculinity as 'the configuration of gender practice which embodies the currently accepted answer to the problem of the legitimacy of patriarchy, which guarantees (or is taken to guarantee) the dominant position of men and the subordination of women' $(2005,77)$. As this gender relation is indeed hegemonic in the Gramscian sense, it does not necessarily operate through the exertion of brute force. Instead, as Connell and Messerschmidt (2005) state, it works through social consent, remains mutable, while staying accessible to only a small number of men.

Within this order of gender relations, gay masculinities are subordinated, black masculinities, are marginalized and middle class, heterosexual masculinities are complicit to hegemonic masculinity (Connell 2005). Writers, such as bell hooks (1994) and Patricia Hill Collins (2004) attest to this hierarchal ordering of masculinity. In this vein, sexuality, race, and class all function to take from or add to one's distance to hegemonic masculinity. Within the contemporary context, hegemonic masculinity is accessible only to white, middle and upperclass, heterosexual men, and those with marginalised identities are required to gain limited access to this hegemonic masculinity through complex negotiation of gender, racial and class practices. hooks (1994) describes one of such negotiation using the example of black gangsta rappers in hip-hop culture. hooks states that, within white-supremacist capitalist patriarchy, 'young black males labour in the plantation of misogyny and sexism to produce gangsta rap' (1994, 123) for access to power, capital and hegemonic masculinity. Within this system, black manhood is simultaneously constructed within a vacuum of poverty, violence, and misogyny, which is commodified and consumed through gangsta rap.

For gay men, this misogyny takes the form of distastes towards effeminate gay men or men who act as women (Connell 2005). In this sense, according to Connell (2005), gay men are not simply attracted to male bodies but also attracted to masculinity, thereby complicating their relation to masculinity. On one hand, in their attraction to masculinity, gay men eschew femininity. On the other hand their attraction to masculinity and failure to dominate women through sexual conquest revokes their own masculinity. In addition to this, dominant patriarchal culture, according to Connell constructs gay male sexuality as effeminacy-the lack of masculinity. Inferring from this, in line with Collins' (2004) argument, it can be argued that the construction of black men as not real men and gay men as effeminate leads to the construction of black gay men as weak and effeminate. However, in many ways this inference is invalid.

As art historian Kobena Mercer (1994) states, black masculinity is 'a key site of ideological representation upon which the nation's crisis comes to be dramatized, demonized and dealt with' (160). Taking this into account it is important to note Frantz Fanon's iteration that '[t]he Negro is taken as a terrifying penis' $(2008,136)$. Relating this to Mercer, then, Collins 
(2004) notes that the media represent black masculinity in ways of hypermasculinising black men as criminals or athletes, or feminising them as sissies or sidekicks. On the one hand is the fear of this terrifying penis and on the other is its symbolic castration or feminisation to control this genital boogeyman. Noting these scholars' analysis of the representation of black men, it is comprehensible why this contradicting view of black men as hypermasculine and effeminate exists.

These representations are similar to those of gay men. Film historian Vito Russo (1987) notes that within the guidelines of the 1930s to late 1960s Motion Picture Production Code (also known as the Hays Code), no perverted act in American cinema could escape censoring. Therefore, filmmakers hid their characters' sexuality under subtext-gay men were coded as sissies, mama's boys or pathological killers. After the Stonewall riots and the decriminalisation of homosexuality, gay men became more visible in the media (Gross 2001). However, as media representations of AIDS as the 'gay plague' (Mercer 1994, 154) increased, anxieties about the disease coalesced into homophobia. As Martin Levine and Michael Kimmel (1998) note, gay men 'had a limited range of stigmatized identities from which to choose, including "hopeless neurotics", "moral degenerate", and "nelly queens"” (20), which most men subverted by acting similar to straight men. Mercer (1994) describes this 'clone look, in which gay men adopted very "straight” signifiers of masculinity' (132), noting the racist and fascist connotations within this new aesthetic.

Within this new culture of gay masculinities, race became a defining characteristic of closeness to hegemonic masculinity. Following Ellen Degeneres' coming out and the popularity of Will and Grace (1998), Streitmatter (2009) notes, positive images of white gay men flourished. The media portrayed these gay men as attractive, tasteful, and successful. As advertisers caught on to a demographic of gay male couples with dual incomes and no kids (DINKs), they began marketing directly to this population. Black queer scholar Dwight McBride (2005) notes that white gay men's brand loyalty to Abercrombie and Fitch symbolically de-valued blackness as A\&F's racism in its workplace policies transferred to its erasure of blackness in its catalogues. Therefore, underneath this white middle class hetero/homonormative aesthetic was the unacknowledged culture of racism in the gay community. Consequentially, when black men finally graced Abercrombie's catalogue, they depicted ghettoised hypermasculinity, thus igniting the racial fantasies of the 'homothug' (McBride 2005, 88) or 'trade' (102) within gay culture. Thus, the racial representation of black men as criminals or athletes doubly proliferated within mainstream and gay culture, pervading through live action and animation.

\section{Forbidden Cartoons: From The Boondocks (2005) to Chozen (2014)}

Adult animation and LGBT representation have a key similarity that ties them together. While Karl Cohen (2004) notes that the strict moral guidelines of the Hays Code censored animators from depicting controversial characters, Russo (1987) describes the ways in which these moral guidelines erased LGBT representation by banning the depiction of sexual romance outside of a heterosexual matrimonial context. From the 1930s to its elimination in 
the late 1960s, the Hays Code attempted to control representation in American media. For animators, that meant the scrutiny of their work from the stage of character design and illustrating to the screening of their pieces. 'Forbidden animation', Karl Cohen terms the cartoons that pushed the boundary of censorship within and outside the enforcement of this code. Cohen (2004) places shows such as the family sitcom The Simpsons (1989) alongside Bakshi's contentious Coonskin (1975) for its status as the first cartoon to swear on television and push the boundary of censorship. For Cohen (2004) censorship comes in many formsmorality policing censorship morphed to political correctness censorship. However, following the number of successful animated television shows, these forbidden animations grew in number and popularity, now having a whole network-Adult Swim-dedicated to their broadcast.

One of the few animated programs in which the n-word (Fitzpatrick 2011) is used liberally, the forbidden cartoon The Boondocks is an anime-style 2D Adult Swim television show that ran for four seasons. The show follows the lives of two black brothers who moved from a multi-ethnic Chicago neighborhood with their grandfather to the predominantly white suburbs of Woodcrest. Most of their adventures stem from failure to fit into the white suburban world. This show reflects aspects of satirised black revolt from the perspective of the homeboy-gangster-rap-enthusiast Riley; his large-Afro-headed-socially-conscious brother Huey Freeman; and their grandfather, the loud-mouthed self-proclaimed Civil Rights veteran Robert Freeman (also know as Grand Dad). Focusing on these three main characters, the award-winning satire reflects the systemic racism and subjugation of black people. It satirises events in pop culture and hip-hop culture, all the while re-contextualising historical racist tropes within the contemporary American suburb. Noting its penchant for controversial commentary on pop culture, Time magazine ranks it number six in a list of ten animated films and programs (Fitzpatrick 2011). For its erudite analysis of racial issues in America, the series is a canonical text in animation. Within the context of this article it proves its position as a definitive text as it admirably foreshadows most of the signs of black gay men reified in other adult animation television shows in popular culture. However, within The Boondocks, the key texts of focus will be the episodes that represent black gay characters or male-male sexual desire in their dominant storyline.

American Dad!, a Seth MacFarlane project, chronicles the life of Stan Smith, conservative CIA agent. As a father figure, most of the episodes address the Stan's anxieties of masculinity as he relates with his nuclear family made up of his wife, two children, and the pansexual, gender-bending alien with a multiple personalities Roger. Aside from Roger, this television show has a number of gay and bisexual men in its character roster. Amongst these characters are the Smiths' neighbors, the gay couple Terry Bates and Greg Corbin; Stan's boss and Deputy Director of the CIA, Avery Bullock (voiced by Patrick Stewart); and Steve's high school principal, Brian Lewis. Of all these characters, Brian Lewis is the only black person in the list. His actions are therefore frequently racialised. The focal point of the analysis of Brian Lewis' masculinity in this article is the episode in which he reunites with his prison partner. 
Another racialised MacFarlane character, Cleveland Brown from The Cleveland Show, has been the subject of debate. With its eponymous character voiced by a white actor, Mike Henry, and its origins in Family Guy (1999), this show bears criticism as 'Family Guy in blackface' (McWhorter 2009). It highlights another racial issue in the animation industry, wherein white voice actors play black characters. In the documentary, I Know That Voice (2013), Gary Anthony Williams and Cedric Yarborough (both black voice actors on The Boondocks) address this issue. While it is beyond the scope of this article to delve into the racial representation in the animation industry, the documentary investigates what informs these white voice actors' representation of races (and sexualities) other than theirs. The four seasons of The Cleveland Show concentrate on Cleveland Brown's relocation from Quahog to a southern suburb in Stoolbend, Virginia. Cleveland's mission in Stoolbend is partly one of proving that he is a 'real man' on his own accord as the patriarch in his new blended family consisting of his new wife Donna and their children (Carter 2010). The focal text within this article is the episode in which the only black gay recurring character-Donna's mother figure-Auntie Momma/Uncle Kevin joins the family.

Drawing close similarities to The Boondocks, Chozen is a satire on hip-hop culture, its objectification of women and its anxieties concerning male-same sex desire (Hill 2009). Focusing on the recently released ex-convict, Phillip "Chozen" Cullens, this program chronicles this gay white man adapting to life outside of the prison as he attempts to dethrone the most influential rapper of his time (and childhood friend-turned-enemy), Phantasm, who is voiced by legendary rapper, Method Man. As noted in Andres Tardio’s (2014) article, this program did not air without some contentions from the hip-hop community. Most criticism went towards the rapper Method Man for his support of this gay-themed cartoon. Although Method Man succeeded in thwarting off the homophobia within these contentions, the producers and cast of this show never address this issue of race and appropriation within Chozen (Halterman 2014). While the show only lasted for one season, the episode depicting Chozen's relationship with the white frat boy Hunter in contrast with his former prison partner Jamal offers a tangible opportunity to analyse the juxtaposition of race and hegemonic masculinity within the gay community.

\section{Signs of Hegemony: Male Matriarchs, Booty Warriors, and Homo-Thugs}

The Boondocks episode 'Pause' portrays the three oft-characterised signs of black gay men in adult animation. The matriarch personified by the character Winston Jerome/Ma Dukes; the booty warrior personified by a prisoner with the same alias; and the homothug, personified by rapper Gangstalicious. These characters, as will be expanded on in this section, connote the subjugation of black masculinity in the system of hegemonic masculinity. As explained this section, the histories of the representation of these characters are rooted in earlier signs of black women, black men and gay men. The oldest sign out of this trio is that of the matriarch. Black matriarchy is simultaneously a myth (hooks, 1992) and a historically rooted (Collins, 2000). Collins (2000) traces this black matriarchy to its origins back to the mammy slavefigure. The scholar differentiates them noting that while 'the mammy typifies the Black mother figure in White homes, the matriarch symbolizes the mother figure in Black homes. 
As the mammy represents the "good" Black mother, the matriarch symbolizes the "bad" Black mother' (75).

A drag rendition of this black matriarch, Ma Dukes characterises feminised 'excess' (Ngai 2005). She is the alter ego of Winston Jerome the leader of a homoerotic Christian theatre troupe and lampoon on the media powerhouse Tyler Perry. Similar to Perry, Jerome's success is based on his role as a black man playing a 'gun-toting, sassy, buxom mother figure' in her sexual prime (Crouse 2006, 2). Ma Dukes also draws from the genealogy of the drag matriarch, which includes Eddie Murphy's Grand Ma Klumps character in Nutty Professor (1996) and Martin Lawrence's eponymous character in Big Momma's House (2000). What then separates The Boondocks' satire of this pervasive trope is Jerome's deployment of drag to cover up his desire for men. Connecting this family of male matriarchs from Tyler Perry's Madea to Ma Dukes and to Auntie Momma in The Cleveland Show, LeRhonda ManigaultBryant (2014) brilliantly asserts the queerphobia in The Boondocks' representation of Ma Dukes and TCS' depiction of Auntie Momma (Manigault-Bryant 2014, 172). Similar to Ma Dukes, Manigault-Bryant emphasises (2014), Auntie Momma uses drag as a cover to have sex with men. However, given her devotion to her niece Donna, Auntie Momma is truly maternal. The rambunctious elderly lady reveals to Cleveland that he (as Uncle Kevin) had to take on the role of Donna's mother figure and caretaker when her parents abandoned her. This performance of the good mother, however, is disrupted as Auntie Momma quickly becomes 'bad black mother' (Collins 2000) when she sleeps with Cleveland's married father, Freight Train, who is unaware that she is a man. Thus, Auntie Momma's queerness 'troubles the heteronormative black family' (Carter 2010, 504). Furthermore, she embodies 'excess' (Ngai 2005) not only in her sexuality but also in her gender-bending demeanor and catchphrase-'I'm outrageous'—which she says while simultaneously cutting the air.

Speaking to this excess is the moment where Auntie Momma simulates fellatio on a turkey leg at the family diner. Watching this confirms Cleveland's doubts that Auntie Momma and his father had sex. Filled with disgust, he projectile vomits three times. Freight Train replicates this reaction when Cleveland coyly informs him of Auntie Momma's secret. As Derrais Carter (2010) notes, 'Freight's reaction, just as Cleveland's, reinscribes Auntie Momma's difference as repulsive and ultimately an unsavory component of black family life' (507). However, her presence serves a purpose in the strengthening of hegemonic masculinity within the show. These aforementioned representations of black gay effeminacy coalesced into the male matriarch emphasise this reliance. However, within these representations of masculinity are aspects of misogyny against black womanhood. As hooks (1992) notes, the object of derision and scorn when a black man does drag for the white gaze is not the man himself but black women. As the critical scholar states ' $\mathrm{t}$ ] hese televised images of black men in drag were never subversive; they helped sustain sexism and racism’ (hooks 1992, 146).

The second common sign of black gay masculinity is that of the 'booty warrior'. An intersection of 'the myth of black rapist' (Davis 1983) and the disproportionately high number of black people in prison (Alexander 2010), this character is a materialisation of the anxieties about loss of masculinity through rape during incarceration. In the episode of The 
Boondocks 'A Date with the Booty Warrior', the Freemans-Riley and Huey-go on a 'Scared Stiff' program after brawling with five other boys at school. Their neighbor, the middle-class lawyer Tom Dubois, who happens to be pathologically scared of prison rape, escorts the 'delinquent youth' to the maximum-security jail where they meet prisoners who all give proselytising speeches. Amongst these prisoners is the symbolisation of sexual 'excess' (Ngai 2005), The Booty Warrior, based on the Kentucky State prisoner Fleece Johnson portrayed in prison reality show Lock Up (2005). Similar to Fleece, The Booty Warrior takes a heightened form of pleasure from sexually assaulting other men. As, imitating Fleece, The Booty Warrior says, 'getting some booty is more important than eating food... it's more important than drinking water'. The Booty Warrior embodies what Angela Davis (1983) emphasises as the anxieties of the 'irrational world of racist ideology' (183). Davis (1983) periodises these anxieties sublimated into the construction of the black rapist to the early 1800s after the emancipation of slaves in America. This myth was created as a pretext for lynching black men. It concretised itself within the binary narrative of the white female victim and the animalistic sexually voracious black man. As shown in The Boondocks and Lock Up, this myth is still perpetuated in the media.

Furthermore, this myth intersects with stereotypes about gay men, as scholars posit that sexual activity within the prison system differs from sexual identity. Stephen Donaldson (2001) notes that 'booty bandits', as the writer terms them, may identify as heterosexual even while they 'engage in sexual coercion' of other men (120). The writer stresses that despite homophobic stereotypes of the 'aggressive homosexual' (121) that surround these booty bandits/warriors, the sexual coercion they exert is more about power and asserting masculinity than sexual preference. The Boondocks illustrates this when time comes for the prisoners to give their speeches. The men all assert that they have all been the victims and perpetrators of rape. However, the in following scenes where a riot erupts and the prisoners make a list of demands, their request for women instead of men highlights their sexual preference.

Indeed power plays an important role in the sexual activity and gender performance of imprisoned men. James Messerschmidt (2001) notes that prison rape offers a dynamic in understanding and interpreting masculine power hierarchies (68). In certain cases men often seek protection from more powerful inmates. Donaldson (2001) calls these 'protective relationships' (123) between 'daddies' and their 'punks'. In some cases, the writer states, when these prisoners within these pairs have longer sentences, they may have a ceremony signifying a matrimonial bond. American Dad! portrays this bond between Brian Lewis, the excessively deviant principal of Pearl Bailey High School, and his 'prison wife' Tracy Bryant. In 'The Worst Stan', the CIA agent unwittingly reunites Lewis with Tracy, as a gift for Lewis' heterosexual wedding to the school superintendent. On his return to the principal's life, Tracy divulges that by prison rules they were 'married' because Lewis beat up his last 'husband'. Therefore, Lewis would be unable marry the female school superintendent and settle into a 'normal' life free of sexual deviancy, crime and drugs. In this sense, similar to Auntie Momma, Tracy's presence revolts against the heteronormative order of the nuclear family. Even more so, Tracy describes their prison marriage as 'three years of wedded bliss'. 
Feelings between Tracy and Lewis reignite, and the principal relapses to his former destructive patterns. Through a series of fights amongst the cast, Tracy becomes 'prison married' to Stan and finally the superintendent, with whom he later on has a child, thus concluding this story with the start of a heterosexual family.

The sign of the booty warrior converges at some points with the third sign - that of the homothug. As a racialised criminal, the booty warrior performs a 'black criminality [...] obsessed with domination-driven masculinity' (Jeffries 2008, 76). Birthed with the late 90s rise of gangster rap, Michael Jeffries (2008) notes, this 'thug' masculinity is a signification in hiphop culture. Therefore, as Marc Lamont Hill (2009) posits, the 'thug' masculinity of the homothug does not necessarily signify 'thuggishness' in its form as racialised criminality. It instead, through the aforementioned system of signs, connotes an affiliation to hip-hop culture. As the writer states, 'homothug refers to a gay or bisexual male who identifies with the hypermasculine accouterments of mainstream hip-hop' (Hill 2009, 46). Hill deconstructs this word, noting its ironic combination of contradictory identities of the oft-feminised gay man and the hypermasculine thug. Hill establishes, '[a]s such, the homothug often represents a human punch line, a walking contradiction that could be looked to for easy insults and quick laughter' (46).

Relating back to Ngai's (2005) concept of 'animatedness' or excess to frame the depiction of the homothug in animation, this character is the convergence of two excesses - that of the 'nelly queen' (Levine and Kimmel 1998, 20) gay man and that of the 'hypermasculine' thug. Introduced in The Boondocks' 'The Story of Gangtsalicious 1', the character Gangstalicious typifies the 'down low' homothug gangster rapper. As Hill (2009) notes, the 'down low' man is one who is discrete about his sexuality. Staying on the 'down low', similar to doing sexual acts in prison, is a performance (Jason King as cited in Hill 2009). Following the association of gay men and HIV (as noted above in Mercer, 1994), this 'DL' man symbolizes the threat of disease, depravity, and destruction of the black family. As a satire of successful mainstream hip-hop artists, Gangstalicious highlights these tensions, including those tensions within hip-hop that support homosocial principles such as 'niggas over bitches' (Hill 2009, 49) while spouting homophobic lyrics in beef songs as a method of 'outing' allegedly gay artists.

In the second chapter of Gangstalicious' story, 'The Story of Ganstalicious 2', the show centres on his fears as a 'down low' gay rapper in hip-hop. In this episode, Gangstalicious attempts to dismiss the hip-hop video girl, who outs him in a tell-all book. By relying on his rendition of hip-hop's misogynist and homosocial creed, 'homies over hoes' (Hill 2009), Gangstalicious attempts to undermine this tattler. The damage, however, is done, as the hiphop community begins to ostracise him. With this final layer, as Gangstalicious falls back on his boyfriend's support, the show reveals him as a vulnerable man who shares a healthy romantic relationship with another black man. Therefore, in this defining moment The Boondocks does not animate Gangstalicious' sexuality as excess. However, according to McBride's (2005) account of the rise of the representation of the homothug or his straightacting down low counterpart, 'trade' within mainstream gay culture, it is debatable that 
Gangstalicious' thug masculinity is a product of gay culture's commodification of the homothug as much as it is a product of hip-hop’s fetishization of ‘thug life' (Jeffries 2008).

This commodification of black identities 'makes it possible [...] for whites to appropriate black culture without interrogating whiteness' (hooks 1992, 154). One of these instances of appropriation of a homothug appears in Chozen, whose eponymous character was raised in a middle class white family, but his proximity to black culture, through his friends Crisco and Ricky offers him an identification with this culture. His relationship with his ex-prison partner Jamal highlights his failure to interrogate his whiteness and privilege compared to his friends. Jamal, a black prisoner, after his release, visits Chozen, disrupting the status quo that the rapper has maintained with his non-convict friends. Subsequently, as the rapper and his new partner, Hunter (a lean white middle class frat boy whose style is reminiscent of Abercrombie and Fitch) are growing apart from each other, Jamal's presence serves to amend Chozen's ennui with Hunter. Due to Chozen's decision to perform at a minor gig with his friends instead of commit a robbery with Jamal the two men fight. Disrupting the fight, the police separate the men but Jamal head butts a police officer. For this assault, the police officers arrest Jamal who breaks out of the police car and dies from the four shots to his chest. Chozen does not mourn Jamal. Instead, in the next scene, Chozen and Hunter celebrate their anniversary at a restaurant.

Jamal's death situates him in the necropolitical order or allocation of death to people based on their marginality (Achille Mbembe 2003). As other marginal people-black people, queer people, and women - he lives across death worlds. In fact, the prison itself is a death world, spatially singled out far beyond borders where criminalised noncitizens reside. The allocation of death to Jamal becomes more evident in that despite Chozen being portrayed as a white man who is heavily influenced by hip-hop culture, his race, class, and position in the hierarchy of masculinity, allocates him a privilege that distances him from the enactment of necropolitics. While Chozen has more adventures, and settles into his hetero/homonormative relationship, Jamal merely becomes another dead black man. The expulsion of Jamal's 'excessive’ (Ngai 2005) ‘thug masculinity' (Hill 2009) refers back to Mercer’s (1994) statement of hegemonic control of black masculinity and Davis’ (1983) historical account of the lynching or murder of black men to assuage racial anxieties.

\section{Black Queer Possibilities: Animatedness, Revolt, and Complicity}

As this paper has previously addressed, the hierarchy of masculinity (Wells 1998) within adult animation has both racialised and sexualised implications for black gay men. Although the characters animated revolt in several manners, the narratives through which they are portrayed show the construction of black gay masculinity as a contradicting form of animated excess (Ngai 2005) in thuggishness, femininity, sexual appetite and criminality. However, in The Boondocks' second chapter on Gangstalicious, the open ending leaves a space for the exploration of black queer possibilities. Halberstam (2011) has noted that it is in this space of radical possibilities that revolt is animated. At the end of this episode, after Gangstalicious has been outed and ostracised, he meets with Riley who has been struggling with his 
sexuality due to his adulation of this rapper. Riley asks Gangstalicious if he is indeed gay. Following a moment of hesitation, Gangstalicious denies his attraction to men. The personification of hip-hop within this show, Riley's self doubt about his sexuality redirects into his preoccupation with the sexuality of his favorite rapper. As Hill (2009) explains, the politics of sexual policing and outing in hip-hop is problematic as '[through] its outing practices, the hip-hop community is able to continuously ignore its own complex sexual ethic by keeping the focus on individual, anonymous, and, in the case of the homothug, aggregate queer bodies' (50). Instead of resolving the episode with a hetero/homonormative ending, Riley and Gangstalicious walk into the horizon, leaving the audience to their own conclusions. In this sense, this show encourages a re-imagination of queerness in its complex multiplicities revolting from within.

\section{References}

Alexander, M. (2010) The new Jim Crow: Mass incarceration in the age of colorblindness, New York: The New Press.

Carter, D. (2010) 'Blackness, animation, and the politics of black fatherhood in The Cleveland Show', Journal of African American Studies, 14(4), 499-508.

Cohen, K. F. (2004) Forbidden animation: Censored cartoons and blacklisted animators in America, North Carolina: McFarland.

Collins, P. H. (2000) Black feminist thought: Knowledge, consciousness, and the politics of empowerment, New York: Routledge.

Collins, P. H. (2004) Black sexual politics: African Americans, gender, and the new racism, New York: Routledge.

Connell, R. (2005) Masculinities, Los Angeles: University of California Press.

Connell, R. \& Messerschmidt, J. (2005) 'Hegemonic masculinity: Rethinking the concept', Gender and Society, 19(6), 829-859.

Crouse, E. (2006). 'We are family', Film Comment, 42, 42-46.

Davis, A. (1983) Women, race and class, New York: Random House.

Donaldson, S. (2001) 'A million jockers, punks, and queens', in D. Sabo, T. A. Kupers, and W. London (eds), Prison masculinities, Philadelphia: Temple University Press, pp. 118-126.

Fanon, F. (2008) Black skin, white masks, London: Pluto Press.

Fitzpatrick, L (2010) 'Top 10 controversial cartoons', Time Magazine, 26 April [Online]. Available at http://entertainment.time.com/2010/04/27/top-10-controversialcartoons/slide/the-censored-eleven/. Access 20 July 2016. 
Gross, L. (2001) Up from invisibility: Lesbians, gay men, and the media in America, Chichester: Columbia University Press.

Hill, M. L. (2009) 'Scared straight: Hip-hop, outing, and the pedagogy of queerness', Review of Education, Pedagogy, and Cultural Studies, 31(1), 29-54.

Halberstam, J. (1998) Female masculinity, Durham: Duke University Press

Halberstam, J. (2011) Queer art of failure, London: Duke University Press.

Halterman, J. (2014) "Chozen" walks the line with gay white rapper at its core', Logo News, 20 January [Online]. Available athttp://www.newnownext.com/chozen-walksthe-line-with-gay-white-rapper-at-its-core/01/2014. Accessed 7 July 2016.

hooks, b. (1992) Black looks: Race and representation, Boston: South End Press.

hooks, b. (1994) Outlaw culture: Resisting representations, New York; London: Routledge.

Jeffries, M. P. (2011) Thug Life: Race, Gender, and the Meaning of Hip-Hop, Chicago: University of Chicago Press.

King, C. R., Lugo-Lugo, C. R., \& Bloodsworth-Lugo, M. K. (2010) Animating Difference: Race, Gender, and Sexuality in Contemporary Films for Children Plymouth: Rowman \& Littlefield Publishers.

Levine, M. and Kimmel, M. (1998) Gay macho: The life and death of the homosexual clone, New York: New York University Press.

Manigault-Bryant, L. (2014) 'Pause, Auntie Momma! Reading religion in Tyler Perry's fat drag', in L. Manigault-Bryant, T. Lomax, and C. Duncan (eds), Womanist and black feminist responses to Tyler Perry's productions, New York: Palgrave Macmillan, pp.165-187.

Mbembe, A. (2003) 'Necropolitics', Public Culture, 15(1), 11-40.

McBride, D. (2005) Why I Hate Abercrombie \& Fitch: Essays on Race and Sexuality, New York: NYU Press.

McWhorter, J. (2009). 'Just a cartoon, but still: Is Family Guy in blackface funny?', The New Republic. 13 October [Online]. Available at http://www.tnr.com/blog/johnmcwhorter/family-guy-blackface-funny. Accessed 20 July 2016.

Mercer, K. (1994) Welcome to the jungle: New positions in Black Cultural Studies, New York: Routledge.

Messerschmidt, J. (2001). 'Masculinities, crime and prison', in D. Sabo, T. A. Kupers, and W. London (eds), Prison masculinities, Philadelphia: Temple University Press, pp. 67-73. 
Ngai, S. (2009) 'Animatedness', Ugly Feelings, Cambridge: Harvard University Press, pp. 89-126.

Russo, V. (1987) The celluloid closet: Homosexuality in the. New York: Harper and Row.

Streitmatter, R. (2009) Perverts to fab five: the media's changing depiction of gay men and lesbians, New York: Routledge.

Tardio, A. (2014) 'Method man blasts critics of "Chozen" TV show about gay white rapper', HiphopDX. 12 January [Online]. Available at http://hiphopdx.com/news/id.27010/title.method-man-blasts-critics-of-chozen-tvshow-about-gay-white-rapper. Accessed 20 July 2016.

Wells, P. (1998) Understanding animation, London: Routledge.

Irene Fubara-Manuel is a practice-based researcher and 3rd-year Doctoral student in Creative and Critical Practice at the University of Sussex. Her ongoing research incorporates animation in interrogating the biometric surveillance of black migrants. Her most recent projects include an installation (Border Ritual) and a video game (Border Ritual 2.0), which both present interventions of the process of crossing the UK Border as a black migrant.

Email: irenefubara@live.ca 